\title{
Confucianism and Autocracy
}





\title{
Confucianism and Autocracy
}

PROFESSIONAL ELITES

IN THE FOUNDING OF

THE MING DYNASTY

John W. Dardess

\author{
University \\ of California \\ Press - Berkeley \\ Los Angeles \\ London
}


University of California Press

Berkeley and Los Angeles, California

University of California Press, Lid.

London, England

O 1983 by

The Regents of the University of California

Printed in the United States of America

1234566789

\section{Library of Congress Cataloging in Publication Data}

Dardess, John W., 1937-

Confucianism and autocracy.

Professional elites in the founding of the Ming dynasty.

Bibliography: p.

Includes index.

1. China-Politics and government-1368-1644.

2. Neo-Confucianism-China. 3. Elite (Social science)

-China. 1. Title.

1215091983

$951^{\prime} .026$

82-4822

ISBN 0-520-04659-5

AMCR2

ISBN 0-520-04733-8 (pbk.) 
To my parents:

John Dardess, M.D.

Edna W. Dardess 
